\title{
A European Perspective on the Higher Education in Romania
}

\author{
Simona Stanciu* \\ Department of Sociology and Social Work, University of Oradea, Oradea, Romania \\ Corresponding author: stanciu_simona@yahoo.com \\ Received May 12, 2014; Revised June 23, 2014; Accepted July 07, 2014
}

\begin{abstract}
This paper aims at offering an overview and a theoretical framework of the national specific of the Romanian Higher Education and the challenges that lie ahead for a common European approach to education (the Bologna process and the European Higher Education Area- EHEA). We examine the National Qualifications in the EHEA Framework by addressing aspects such as degree cycles; qualification levels; types of diplomas; quality assurance; credit transfer system and Diploma Supplement. A critical argumentation in terms of learning outcomes translatability and recognition of academic and professional qualifications is addressed. Also, we shortly present some challenges concerning the student population (underrepresented groups; student fees and scholarships; student mobility).The research methodology comprises a thorough literature review of the national policy as it is the decisive factor for the Romanian education system (the National Law of Education from 2011 and the latest Governmental Decisions; the National Qualifications Authority's Self-certification Report 2011; and data produced by other accredited Romanian Agencies, such as the Romanian Agency for Quality Assurance and the National Centre for Recognition and Equivalence of Diplomas). Also, a main piece of literature that was of great importance is the European Union's institutional perspective (data provided by the European Commission Eurostat- the statistical office of the European Union; Information Centres, and European Students' Union), along with scientific studies in the area of higher education. Understanding the comparability mechanisms in tertiary education provides a common ground for bettering students and work-force mobility around the Globe.
\end{abstract}

Keywords: higher education, qualifications, learning outcomes, challenges, Romania

Cite This Article: Simona Stanciu, "A European Perspective on the Higher Education in Romania." American Journal of Educational Research, vol. 2, no. 7 (2014): 526-532. doi: 10.12691/education-2-7-15.

\section{Introduction}

After 1990, the Romanian education system underwent a continuous reform which was both criticized and praised. A new Law of Education was enforced in 1995 that states that higher education in Romania builds upon a set of principles combining university autonomy with public accountability of higher education institutions. The national framework of qualifications compatible with the European Qualifications Framework was developed by the National Agency for Qualification in Higher Education at the end of 2005. The Law of Education was replaced by the 2011 law which amplified the reorganization process in the learning system.

Just like in other socialist countries before 1989, the centralized system permitted a limited access to higher education in Romania. One of the main goals of the reform in higher education is free access to education guaranteed for every citizen.

The number of students grew considerably in Romania, with $60.2 \%$ between the 2003/04 and 2008/09 academic years, while in general, the student population increased by more than $10.4 \%$ in half of the EHEA countries in this period. Yet the enrolment in tertiary education (for the 18-
34 years old), remains low in Romania: $16.8 \%$ of the total population in 2009 [1].

The number of tertiary education institutions and programmes increased both in the public and private sector in the post-revolution period. University education has historical roots in Romania, approximately 20\% of universities are over 100 years old of the total higher education institutions and 50\% are younger than 20 years. During the 2009/10 academic year, 109 active higher education institutions (of which 56 accredited public institutions, 35 accredited private higher education institutions, and 21 provisionally approved private institution). About 330 first cycle programmes (Bachelor) within 74 study fields have been offered. The estimated number of second cycle (Master) programmes of 3-4 semesters (90 to 120 ECTS) was 2570, and 57 universities and the Romania Academy were granted the right to develop third cycle programmes (doctoral studies), according to the data provided by the Ministry of Education [2].

Despite the fact the student population became fourtime larger during the past two decades, yet the expected coping effect with the demand for tertiary education delays in instauration. In the context of a shrinking population, and with more than 3 million emigrants out of 19.5 million population Romania rated 414 students in 
10,000 inhabitants in 2009, according to the statistics annual [3].

Chronic underfinancing in education as one of the main issues (6\% of GDP), and recent reports confirmed the fact that the financial support investing in human capital is quite dispersed, diminishing the amplitude of results [4].

\section{Bologna Process and the European Higher Education Area}

The Bologna reforms changed the face of higher education across Europe and its implications spread globally. Currently, forty-seven European countries are signatories to the Bologna Process. Also, countries outside Europe such as New Zealand, Australia or Canada consider their own alignment to the Bologna Process and comparability mechanisms in tertiary education, according to the European Commission [5].

Romania signed the Bologna Declaration in 1999 and committed to the development of the European Higher Education Area. Measures adopted afterwards concern the compatibility of the Romanian higher education with the European standards while fostering individual and institutional competitiveness. The national system underwent a rearrangement process by following the Bologna recommendations on the three study higher education cycles, the implementation of the credit transfer system (ECTS) and of the Diploma Supplement [6].

\subsection{Bologna Degree Cycles}

Complying with the Bologna system across Europe, Romanian higher education institutions offers courses based on three study cycles: Bachelor, Master and Doctorate, as shown in Table 1. The long term higher education programmes (usually 5 years of study) were replaced by bachelor degree and master's degree programmes starting in the academic year 2005-2006 and in most study fields, the process was accomplished in 2008-2009. The 6-years Doctoral studies (PhD) were replaced by 3 years long lasting studies since 2006. Also, post-university training programmes and personal development studies are provided in the framework of lifelong learning in higher education $[7,8]$.

\subsection{Qualification levels in Higher Education}

The three study cycles Bachelor, Master and Doctorate are legally mapped against levels 6,7 and 8 of the European Qualifications Framework (Table 2).

Table 1. Bologna Degree Cycles

\begin{tabular}{|c|c|c|}
\hline First Cycle & $\begin{array}{c}\text { Bachelors } \\
\text { Degrees }\end{array}$ & Minimum of three years study; 180 ECTS or achieving the relevant EHEA Qualifications Framework outcomes. \\
\hline $\begin{array}{c}\text { Second } \\
\text { Cycle }\end{array}$ & $\begin{array}{c}\text { Masters } \\
\text { Degrees }\end{array}$ & Generally two years study; 120 ECTS or achieving therelevant EHEA Qualifications Framework outcomes. \\
\hline $\begin{array}{c}\text { Third } \\
\text { Cycle }\end{array}$ & $\begin{array}{c}\text { Doctoral } \\
\text { Degrees }\end{array}$ & Generally three years study; or meeting the relevant EHEA Qualifications Framework outcomes. Third cycle \\
qualifications do not necessarily have credits associated with them.
\end{tabular}

Table 2. Qualifications of the three cycle in the Romanian higher education

\begin{tabular}{|c|c|c|c|c|}
\hline & $\begin{array}{c}\text { National Qualifications } \\
\text { Framework for Higher } \\
\text { Education in Romania }\end{array}$ & $\begin{array}{c}\text { Framework for Qualifications of the } \\
\text { European Higher } \\
\text { Education Area }\end{array}$ & $\begin{array}{c}\text { Romania's National } \\
\text { Qualifications } \\
\text { Framework }\end{array}$ & $\begin{array}{c}\text { European Qualifications } \\
\text { Frame } \\
\text { work for Lifelong Learning }\end{array}$ \\
\hline \multirow{2}{*}{$\begin{array}{c}\text { Higher } \\
\text { Education }\end{array}$} & Doctorate & Third cycle & Level 8 & Level 8 \\
\cline { 2 - 5 } & Master & Second cycle & Level 7 & Level 7 \\
\cline { 2 - 5 }
\end{tabular}

Table 3. Types of diplomas in Romania

\begin{tabular}{|c|c|c|}
\hline $\begin{array}{c}\text { EHEA } \\
\text { qualification } \\
\text { cycles }\end{array}$ & $\begin{array}{c}\text { Qualifications within the } \\
\text { framework for qualifications } \\
\text { of HEI in Romania }\end{array}$ & $\begin{array}{l}\text { About Diplomas in Romania } \\
\text { According to the National Education Law no 1/2011 and Governmental Decision 567/2005 }\end{array}$ \\
\hline $\begin{array}{l}\text { First cycle } \\
\text { qualifica } \\
\text { tions }\end{array}$ & $\begin{array}{c}\text { Bachelor/ } \\
\text { engineer/ } \\
\text { medical doctor, } \\
\text { urban planner diploma }\end{array}$ & $\begin{array}{c}\text { • provided after a successful completion of full-time, part-time or distance learning education; } \\
\text { - usually cover a work load corresponding to a minimum of } 180 \text { ECTS ( } 3 \text { years programmes), may } \\
\text { reach in some fields of study a maximum of } 240 \text { ECTS (4 years programme); } \\
\text { • exceptions in case of study programmes leading to qualifications corresponding to EU regulated } \\
\text { professions (for pharmacy studies the workload corresponds to } 300 \text { ECTS and the duration of a full } \\
\text { study programme is of } 5 \text { years; for medicine, dental medicine and veterinary medicine the workload } \\
\text { is of } 360 \text { ECTS and the duration is of } 6 \text { academic years). } \\
\text { - issued free of charge with Diploma Supplements drafted in Romanian and in English for all } \\
\text { graduates who successfully passed the final examination. }\end{array}$ \\
\hline $\begin{array}{l}\text { Second cycle } \\
\text { qualifica } \\
\text { tions }\end{array}$ & Master diploma & $\begin{array}{l}\text { • provided after the successful completion of full-time or part-time education; } \\
\text { • cover a workload of minimum } 60 \text { and maximum } 120 \text { ECTS ( } 1 \text { or } 2 \text { years duration), } \\
\text { • for professions regulated by European legislation, recommendations or good practices, the first } \\
\text { and second cycles of higher education may be provided within one study programme with 5-6 year } \\
\text { duration, fulltime mode and the graduation diplomas are equivalent to the Master's degree ones; } \\
\text { • issued free of charge with Diploma Supplements drafted in Romanian and an international } \\
\text { language upon successful completion of a Master's study programme and presentation of } \\
\text { dissertation. }\end{array}$ \\
\hline $\begin{array}{l}\text { Third cycle } \\
\text { qualifications }\end{array}$ & $\begin{array}{l}\text { PhD Scientific/ Professional } \\
\text { (in the fields of arts and } \\
\text { sport) diploma }\end{array}$ & $\begin{array}{l}\bullet \text { provided only after a successful completion of full-time programmes; } \\
\bullet 60 \text { ECTS are compulsory for each doctoral program (duration on average } 3 \text { years) } \\
\text { • indicates specifically the disciplinary or the inter-disciplinary field for the scientific doctorate or } \\
\text { the professional field for the professional doctorate. }\end{array}$ \\
\hline
\end{tabular}

\subsection{Types of Diplomas and Awards}

The qualifications acquired by the graduates of higher education study programmes in Romania are attested by 3 types of diplomas: Bachelor/engineer/medical doctor, urban planner diploma, Master diploma and $\mathrm{PhD}$ diploma (Table 3). Besides the three study cycles, competences acquired through post-university continuing training and 
personal development studies do not lead to qualifications, but are attested by certificates and other documents. These documents are issued only by accredited higher education institutions and only for accredited study programmes and modes, according to the National Education Law 1/2011 [9].

The university categories issuing diplomas and certificates are universities focused on education; tertiary education institutions focused on education and scientific research /or focused on education and artistic creation, and universities focused on advanced research and education.

\section{The Framework of Qualifications for the European Higher Education Area and the National Qualification Framework}

The Qualifications Framework in the European Higher Education Area (QF/EHEA) was adopted in 2005 by European Ministers of Education, and the European Qualifications Framework for Lifelong Learning (EQF) was published in 2008 as the full development of the National Qualifications Framework (NQF) covering all eight levels of qualification. Based on the EQF, the
National Qualifications Framework was developed by the National Agency for Qualification in Higher Education (ACPART) at the end of 2005. The Executive Unit of the National Qualifications and Adult Training Council (UECNCFPA) became the National Coordination Point for the NQF in 2010. NQF is an instrument for the classification of qualifications against a set of criteria related to specific learning levels from a lifelong learning perspective, in order to provide international transparency of the learning outcomes, according to the 2011 law in education.

The National Qualification Framework was developed since 2006 in order to be fully compliant with requirements stated by the Bergen Report. The first draft of the Self certification Report was drafted and official launched in 2011. The NQF is fully compatible with the European Framework for Higher Education [10]. Qualifications compatibility aim to facilitate the mobility of students and workers in the EU, to stimulate "brain mobility” and fair employment, especially of youth. A comprehensive description of the learning outcomes for each study programme is supported by an electronic platform: the National Register of Qualifications in Higher Education -RNCIS.

\subsection{Learning Outcomes}

Table 4. The framework of qualifications for the European Higher Education Area

\begin{tabular}{|c|c|}
\hline Outcomes & ECTS Credits \\
\hline $\begin{array}{c}\text { First cycle qualification: Qualifications that signify completion of the first cycle are awarded to students } \\
\text { who: } \\
\text { • have demonstrated knowledge and understanding in a field of study that builds upon their general } \\
\text { secondary education, and is typically at a level that, whilst supported by advanced textbooks, includes some } \\
\text { aspects that will be informed by knowledge of the forefront of their field of study; } \\
\text { • can apply their knowledge and understanding in a manner that indicates a professional approach to their } \\
\text { work or vocation, and have competences typically demonstrated through devising and sustaining arguments } \\
\text { and solving problems within their field of study; } \\
\text { • have the ability to gather and interpret relevant data (usually within their field of study) to inform } \\
\text { judgments that include reflection on relevant social, scientific or ethical issues; } \\
\text { - can communicate information, ideas, problems and solutions to both specialist and non-specialist audiences; } \\
\text { - have developed those learning skills that are necessary for them to continue to undertake further study with } \\
\text { a high degree of autonomy. }\end{array}$ & $\begin{array}{l}\text { Typically include 180-240 ECTS } \\
\text { credits }\end{array}$ \\
\hline $\begin{array}{l}\text { Second cycle qualification: Qualifications that signify completion of the second cycle are awarded to } \\
\text { students who: } \\
\text { • have demonstrated knowledge and understanding that is founded upon and extends and/or enhances that } \\
\text { typically associated with the first cycle, and that provides a basis or opportunity for originality in developing } \\
\text { and/or applying ideas, often within a research context; } \\
\text { • can apply their knowledge and understanding, and problem solving abilities in new or unfamiliar } \\
\text { environments within broader (or multidisciplinary) contexts related to their field of study; } \\
\text { • have the ability to integrate knowledge and handle complexity, and formulate judgments with incomplete or } \\
\text { limited information, but that include reflecting on social and ethical responsibilities linked to the application } \\
\text { of their knowledge and judgments; } \\
\text { - can communicate their conclusions, and the knowledge and rationale underpinning these, to specialist and } \\
\text { nonspecialist audiences clearly and unambiguously; } \\
\text { - have the learning skills to allow them to continue to study in a manner that may be largely self-directed or } \\
\text { autonomous. }\end{array}$ & $\begin{array}{l}\text { Typically include } 90-120 \text { ECTS } \\
\text { credits, with a minimum of } 60 \text { credits } \\
\text { at the level of the } 2 \text { nd cycle }\end{array}$ \\
\hline $\begin{array}{l}\text { Third cycle qualification: Qualifications that signify completion of the third cycle are awarded to students } \\
\text { who: } \\
\text { - have demonstrated a systematic understanding of a field of study and mastery of the skills and methods of } \\
\text { research associated with that field; } \\
\text { - have demonstrated the ability to conceive, design, implement and adapt a substantial process of research } \\
\text { with scholarly integrity; } \\
\text { - have made a contribution through original research that extends the frontier of knowledge by developing a } \\
\text { substantial body of work, some of which merits national or international refereed publication; } \\
\text { • are capable of critical analysis, evaluation and synthesis of new and complex ideas; } \\
\text { - can communicate with their peers, the larger scholarly community and with society in general about their } \\
\text { areas of expertise; } \\
\text { - can be expected to be able to promote, within academic and professional contexts, technological, social or } \\
\text { cultural advancement in a knowledge based society. }\end{array}$ & Not specified \\
\hline
\end{tabular}

Learning outcomes in the European education area usually represent sets of competences acquired on completion of the studies. The workload is the average

time an average learner might be expected to need in order to reach the required learning outcomes of a full-time student during one academic year (according to European 
Network of Information Centres in the European Region). In the Bologna Process there is no requirement for any minimum student learning hours. The number of ECTS credits awarded depends on qualification level and study programme and is only shown after appropriate assessment of the learning outcomes. In Table 4 are shown the learning outcomes in the European Higher Education Area Framework [11].

\subsection{The European Credit Transfer and Accumulation System (ECTS)}

The European Credit Transfer and Accumulation System is tool for transfer of study achievements, but also for accumulation of workload in the first and second and in the third cycles throughout the area of European higher education. ECTS was established before the Bologna process started as a tool for transfer of study achievements for the Erasmus/Socrates programme. ECTS credits were linked to the workload as a basis for their calculation (ECTS Users' Guide 2005), whereas in 2009 it was specified that "the formulation of learning outcomes is the basis for the estimation of workload and hence for credit allocation” (ECTS Users' Guide 2009). Learning outcomes are linked to implementation of qualifications frameworks and to the paradigm shift towards studentcentred learning approach [12].

In Romania, learning outcomes means statements of what a learner knows, understands and is able to do on completion of a learning process, which are defined in terms of knowledge, skills and competence [13].

All higher education institutions use ECTS for accumulation and transfer for all elements of study programmes. The basis to award ECTS is a combination of learning outcomes and student workload. There is no standard measurement for the number of hours per credit but the reported number of hours per credit is 27 [14].

\subsection{Diploma Supplement}

All national higher education institutions issue free of charge the Diploma Supplement for their graduates from bachelor and master programs [15]. The Diploma Supplement is issued in Romanian language and usually in English, but could be also in French or German.

In Romania, the Diploma Supplement is a compulsory document for all diplomas of bachelor [16], and master programs [17], and for diplomas of professions regulated by European norms, regulations or good practices - where bachelor and master programs can be provided as part of a 5 to 6 year full-time programme of study, those diplomas are recognized as master's degree certificates (as in the following fields of study: Medicine, Dentistry, Pharmacy, Veterinary Medicine, Architecture.

\subsection{Compliance of Compatibility Criteria (Recognition of Qualifications)}

In Romania, the academic and professional recognition is done by the Ministry of Education through the ENIC/NARIC centre for non-regulated professions [18]. The competent authorities for the regulated professions take the decision of recognition for EU citizens. The recognition conditions are stated in the law implementing the Lisbon Convention no. 172/1998 and also there are some references in the Law of national education no. 1/2011. Based on the law implementing the Lisbon Convention, the National Centre ENIC/NARIC has adopted the methodology on the recognition of diplomas through a Ministry Order [19].

Issues on fostering flexible learning and access routes to higher education (such as entry with a school leaving certificate, entry with a vocational education certificate, entry without formal certification etc.) are not regulated by policy measures. There isn't yet any official status on part-time study provision nor an explicit policy to encourage part-time study provision by higher education institutions. Recognition of prior non-formal and informal learning is not yet defined in legislation which neither expressly permits nor prohibits HEIS to implement procedures for validation of non-formal and informal learning.

Widening access to education in order to enable a broader range of individuals to fulfill their potential is a Bologna desiderate. Postgraduate trainings and professional development programmes provided by higher education institutions in the framework of the Lifelong learning process are taken into consideration especially by employed and unemployed adults, and less by retired citizens, part-time students or adults without higher education qualifications.

\subsection{Academic Recognition}

Academic recognition is the evaluation of a diploma/degree obtained abroad in order to determine the equivalent level in the domestic education system by the competent Romanian authority (National Centre for Recognition and Equivalence of Diplomas-CNRED [20].

Foreign degrees are evaluated in terms of the institution status; level of the diploma; no of years of study/no of credits accumulated; field of study; study profile; specialization; curriculum/ workload/ Diploma Supplement; professional qualification. In case of major differences in field and profile, compensatory measures can be proposed: periods of study or aptitude tests/exams, which are applied by accredited universities in Romania. In case of bilateral agreements the recognition of studies and diplomas is done automatically. Bilateral agreements and conventions to which Romania is part of have been enacted with Hungary, Moldova, Bulgaria, Ukraine, Cyprus, Slovakia and Russian Federation. The tools used in recognition are the National Qualifications Framework for Higher Education (NQF), the European system of transferable academic credits (ECTS) and Diploma Supplement [21].

\subsection{Recognition of Professional Qualifications}

Professional recognition is taken into consideration the level of the diploma and the professional experience acquired in other state in order to exercise a profession in Romania. CNRED is the competent authority for professional recognition of qualifications obtained abroad, in order to obtain the work permit issued by the Ministry of Labor.

For the recognition of university academic titles obtained in a Higher Education Institution accredited in a Member State of the European Union, of the European 
Economic Area and in the Swiss Confederation the competent authority is the National Centre for Recognition and Equivalence of Diplomas - CNRED. Certificate of conformity with the European Union directives are issued for non-regulated professional activities in Romania.

A regulated profession is the activity/group of professional activities, whose right to exercise/one of the means of exercising them are conditioned by the possession of specific professional qualifications. For the regulated professions in Romania (doctor, dentist, pharmacist, nurse, midwife, veterinarian doctor and architect) the Certificate of conformity can be issued by the corresponding competent authorities, according to the Law no. 200/2004: Ministry of Health, Order of Architects etc.

\subsection{Quality Assurance}

The internal quality assurance processes for the internal approval monitoring and periodic review of programmes is conducted by Quality Assurance Departments (or Committees) at university level. External review is also in place.

The Romanian Agency for Quality Assurance - an independent public institution [22], verifies the compliance by the evaluated study-programme of criteria and standards set legally, according to the ESG. If all criteria are met, the study-programme/institution is granted an accreditation in order to enroll students, deliver courses and organize final exams and deliver degrees at the end of the cycles, or in case of provisional authorization, to enroll students and deliver courses. Every five years, all accredited study programmes and institutions are subjects to an assessment process in order to obtain re-accreditation. The maximum capacity of enrolled students is established for each year of studies (one of the financing criteria for State universities).

The external quality assurance evaluation takes into consideration: teaching, student support services, research, employability and the Internal Quality Assurance/management system [23].

There are several ongoing strategic projects regarding quality assurance, such as the Romanian Higher Education Improvement Project on University Management and Quality and Leadership in Romanian higher education.

\section{Challenges Concerning the Student Population}

\subsection{Underrepresented Groups}

The State grants social scholarships to students from lower socio-economic environments, as well as to orphan students or those coming from foster care [24], [25]. Study loans for candidates coming from low income families are guaranteed by the state and may cover taxes and life costs during university studies. Free fare on the means of transport can be accessed by institutionalized students.

Also, students coming from high-risk backgrounds or socially marginalized, namely Roma people and high school graduates in the rural areas or small cities (with population less than 10 thousand) may benefit from a number of guaranteed budgeted places [26].
Financial aid and accommodation subsidize are offered for students coming from low income backgrounds, those in foster care and Romanian ethnic minorities from abroad.

\subsection{Student Fees}

Fees payable by home students are according to each HE institution policy; the most common amount is approximately 1000 EUR/ year for first cycle non budgeted places and 2000 EUR/ year for second cycle budgeted places given by Ministry of Education. According to the National Educational Law no 1/2011, for budgeted places there are no fees at all [27].

International students' fees are according to each tertiary institution policy. International students are considered any candidate from the member states of the EU, from the European Economic Space and from the Swiss Confederation may take the admission exam for a public, private or confessional higher education for each educational cycle and program, in the same conditions provided by law for the Romanian citizens [28].

\subsection{Public Grants and Scholarships}

The national education law specifies that public high education system is free, for the amount of students approved by the government, and charged, in the limits of the Law. 25 percentages of first cycle students receives a grant and/or scholarship. Same percentage of students in second cycle receives a grant. Values of grants/scholarships available are: minimum 300 EUR/ year and maximum 1000 EUR/ year, most commonly 300 EUR/year. The non-tax based benefits eligibility criteria are: low income of parents, age of student, disability.

In Romania the public non-cash student support are: subsidized accommodation, subsidized health insurance. Full time students receive accommodation support given by State [29], and also receive 50\% reduction for public transportation [30].

\subsection{Student and Staff Mobility}

The European Higher Education Area's (EHEA) hallmark was designed to be the mobility of students, teachers, early stage researchers and staff mobility. Student mobility increased constantly in Europe. 200,000 students per year do part of their studies abroad through the Erasmus Programme and 2.2 million students have been mobile since 1987 (European Students' Union: Bologna with Student Eyes 2012). According to Eurostat database, $2.1 \%$ of EU students participated in mobility in 2000 (1.5\% of Romanian students) and 3.1\% of EU-27 countries (3.9\% of Romanian students) [31]. By 2020, at least $20 \%$ of those graduating in the EHEA should have had a study or training period abroad (Leuven Communiqué).

Lately, the mobility flows have become a central point of focus, with increasing emphasis on attracting students from outside the EU or EHEA. Significant imbalances in mobility flows between continents, countries, regions and institutions have been stated. Statistics show more outgoing than incoming students (according to the National Institute of Statistics for incoming, OECD data basis/ Eurostat for outgoing students). The mobility flows are most imbalanced with USA, Canada and Western 
Europe (more outgoing students than incoming) and with Eastern Europe and neighboring countries: more incoming than outgoing [32].

The European Ministers have supported the concept of "balanced mobility" in the 2009 Bologna Policy Forum Statement. Therefore, most EU countries pay more attention to balancing the mobility flows. The European strategy for mobility proposed to adopt in the 2012 Bucharest Ministerial Conference needs to be used as a tool to remove the remaining barriers.

The national strategy to foster mobility is materialized in several national policies, regulated by legal acts. Initiatives are focused on financial incentives/scholarships to foster mobility (e.g. scholarships scheme for studies, doctorate and specialization and other forms of support for students having Romanian nationality from neighboring countries or for Romanian diaspora abroad; scholarships scheme for study periods abroad for Romanian undergraduate and graduate students; additional governmental support for Romanian students abroad on the basis of a bilateral or unilateral governmental agreement; scholarships scheme for graduate research or graduate study periods abroad in EU policies area (Ministry of Education/ National Centre for Recognition and Equivalence of Diplomas Granted Abroad). Recognition of periods of study completed at other universities by Romanian students (facilitated by the implementation of the National Qualifications Register), and applying Gravier regarding the access of EU students in Romanian universities, are steps taken towards increasing student mobility, and improving student completion rate.

Results of an inquiry on student and staff mobility [33] show some particular geographic regions which are given priority for student and/or staff mobility in the national strategy (Table 5).

Table 5. Priority Regions for student and/or staff mobility

\begin{tabular}{|c|c|c|c|c|}
\hline $\begin{array}{c}\text { Priority } \\
\text { Region }\end{array}$ & $\begin{array}{c}\text { Incoming } \\
\text { students }\end{array}$ & $\begin{array}{c}\text { Outgoing } \\
\text { students }\end{array}$ & $\begin{array}{c}\text { Incoming } \\
\text { staff }\end{array}$ & $\begin{array}{c}\text { Outgoing } \\
\text { staff }\end{array}$ \\
\hline EHEA & Y s & yes & yes & yes \\
\hline $\begin{array}{c}\text { Middle } \\
\text { East }\end{array}$ & yes & & & \\
\hline Africa & yes & & & \\
\hline
\end{tabular}

The support measures implemented to foster student mobility include special service for international students offered by all Romanian universities which can offer accommodation to foreign students under the same conditions as for Romanian students or have special accommodation facilities for foreign students paying tuition fees.

Table 6. Obstacles to student mobility (most important $=1$, second most important $=2$, and third most important $=3$ )

\begin{tabular}{|c|c|c|}
\hline $\begin{array}{c}\text { Obstacles to student } \\
\text { mobility }\end{array}$ & Incoming mobility & $\begin{array}{l}\text { Outgoing } \\
\text { mobility }\end{array}$ \\
\hline Funding & & 1 \\
\hline Recognition & & 2 \\
\hline Language & 2 & \\
\hline \multicolumn{3}{|l|}{$\begin{array}{l}\text { Curriculum/Study } \\
\text { organization }\end{array}$} \\
\hline Legal issues & 3 & \\
\hline $\begin{array}{c}\text { Motivating and } \\
\text { informing students }\end{array}$ & 1 & 3 \\
\hline Other, please specify: & $\begin{array}{l}\text { Immigration restrictions } \\
\text { (included in legal issues) }\end{array}$ & \\
\hline
\end{tabular}

The most important obstacles to student mobility addressed in national measures highlighted by the inquiry are: motivation especially for outgoing students, immigration restrictions and language issues for incoming mobility, and recognition of disciplines for outgoing students (Table 6).

The obstacles of staff mobility are the lack of motivation for outgoing mobility, legal issues such as employment arrangements or double taxing for incoming staff, and language issues for both forms of mobility (Table 7).

Table 7. Obstacles to staff mobility (most important $=1$, second most important $=2$, and third most important $=3$ )

\begin{tabular}{|c|c|c|}
\hline $\begin{array}{c}\text { Obstacles to staff } \\
\text { mobility }\end{array}$ & Incoming mobility & $\begin{array}{l}\text { Outgoing } \\
\text { mobility }\end{array}$ \\
\hline \multicolumn{3}{|l|}{ Immigration restrictions } \\
\hline \multicolumn{3}{|l|}{ Recognition issues } \\
\hline Language issues & 1 & 1 \\
\hline \multicolumn{3}{|l|}{$\begin{array}{l}\text { Incompatibility of } \\
\text { pension and/or social } \\
\text { security systems }\end{array}$} \\
\hline Legal issues & $\begin{array}{l}2 \text { (employment } \\
\text { arrangements, double } \\
\text { taxing issue etc.) }\end{array}$ & \\
\hline Other, please specify: & lack of information & $\begin{array}{c}\text { lack of } \\
\text { motivation of the } \\
\text { academic staff } 2\end{array}$ \\
\hline
\end{tabular}

More recent study conducted by student unions in 27 EHEA countries, including Romania, identifies the biggest obstacles for student mobility: financing and lack of financial support (22\%); recognition (10\%); lack of information and guidance and support, other than financial (9\%); lack of flexibility or no mobility window (7\%); lack of motivation or other personal reasons such as work, family or home sickness (7\%), and language (5\%) [34].

\section{Conclusions}

Financial constraints and chronic under financing in education (6\% of GDP) represent some of the main issues for the Romanian universities.

The higher education institutions strive constantly to obtain financial resources and also prestige. The education system is relatively homogenous in terms of traditions: about $80 \%$ of the higher education institutions are less the 100 years old, but the current classification and grading process is not perceived to be fully competent. Increasing prestige requests also innovative research centres affiliated to universities and students' access to research in bachelor, master and doctoral studies.

The proportion of educated population remains still low in Romania: $16 \%$ of the $25-34$ years old population is higher educated, compared to 29.9\% in the EU (according to the Eurostat data). One of the main reasons is the dropout phenomenon: the average time spent by Romanian students in university is only 1.5 years.

After more than ten years of mobility focus within the Bologna Process, mobility is still mainly available to students from stable or privileged socioeconomic background. The imbalanced mobility flows in Europe seem to be causing disputes over the financing policies. More successful student exchanges are made between association of universities, or universities (groups of students coming in Romania from Germany, for example) in the context of comparable curricula ( $90 \%$ compatibility 
in the EU for the Erasmus programme). The European higher institutions attract also students from outside the UE. $2.23 \%$ of the students in Romania are foreigners, of which 59\% are from Moldova Republic, while 54\% EU foreign students come from Africa and Americas. In Romania, the steps made towards the increase of incoming flows from outside of the EU stop at governmental level because of long and difficult formalities (longer than a month for the Chinese students, e.g.). Romanian students prefer universities in UK and USA.

Indicators show just $17.5 \%$ adult learning in Romania (last in the UE), pointing to the necessity of developing a lifelong learning mentality towards flexible careers.

\section{References}

[1] EACEA; Eurydice; Eurostat; Eurostudent. "The European Higher Education Area in 2012: Bologna Process Implementation Report”. Brussels: Eurydice. ISBN 978-92-9201-256-4. [Online]. Available: www.ehea.info/Uploads/(1)/Bologna\%20Process\%20Implementat ion\%20Report.pdf. [Accessed Dec. 1, 2013].

[2] Ministry of Education, Research, Youth and Sports. "National Report regarding the Bologna Process implementation 2009-2012”. [Online]. Available: www.ehea.info/Uploads/National\%20reports/Romania\%20Rep\%2 0and\%20Annex.pdf. [Accessed Dec. 1, 2013].

[3] National Institute of Statistics. Romanian Statistical Yearbook 2008.

[4] Neagu, G. "Innovation in education". A Journal Dedicated to Quality of Life and Social Policy, Issue 1-2, 2009. [Online]. Available:http://www.revistacalitateavietii.ro/2009/CV-1-22009/12.pdf. [Accessed Dec. 3, 2011].

[5] European Commission. [Online]. Available: http://ec.europa.eu/education/highereducation/bologna_en.htm.[Accessed Dec. 1, 2013].

[6] European Higher Education Area - EHEA. "Bologna Process. EHEA National Reports- Romania 2009-2012”. [Online]. Available:

www.ehea.info/Uploads/National\%20reports/Romania\%20Rep\%2 0and\%20Annex.pdf. [Accessed Oct. 15, 2013].

[7] Romanian National Centre for Recognition and Equivalence of Diplomas- CNRED. "Self-certification Report. Verification of compatibility of the Romanian National Qualifications Framework for Higher Education with the Framework for Qualifications of the European Higher Education Area. Document for further consultation and implementation. November 2011”. [Online]. Available:

http://cnred.edu.ro/pdf/Self_certification_Report_RO_2011.pdf. [Accessed Dec. 1, 2013].

[8] Ministry of Education, Research, Youth and Sports. "National Report regarding the Bologna Process implementation 2009-2012". [Online]. Available: www.ehea.info/Uploads/National\%20reports/Romania\%20Rep\%2 0and\%20Annex.pdf. [Accessed Dec. 1, 2013].

[9] Ministry of Education. National Education Law 1/2011, art. 173.

[10] Ministry of Education and Research. Ministerial Order no. 4430/29.06.2009.

[11] The official Bologna Process website July 2007 - June 2010. "Overarching framework of qualifications of the EHEA". [Online]. Available:

www.ond.vlaanderen.be/hogeronderwijs/bologna/qf/overarching.a sp.[Accessed Dec. 3, 2011].

[12] EACEA; Eurydice; Eurostat; Eurostudent. "The European Higher Education Area in 2012: Bologna Process Implementation Report". Brussels: Eurydice. ISBN 978-92-9201-256-4. [Online]. Available: www.ehea.info/Uploads/(1)/Bologna\%20Process\%20Implementat ion\%20Report.pdf. [Accessed Dec. 1, 2013].

[13] Ministry of Education and Research. Ministerial Order no. $4430 / 29.06 .2009$.
[14] Ministry of Education, Research, Youth and Sports. "National Report regarding the Bologna Process implementation 2009-2012". [Online]. Available: www.ehea.info/Uploads/National\%20reports/Romania\%20Rep\%2 0and\%20Annex.pdf. [Accessed Dec. 1, 2013].

[15] Ministry of Education. Law no. 288/2004.

[16] Ministry of Education and Research. Minister Order no. 5289/2008.

[17] Ministry of Education and Research. Minister Order no. $4151 / 2010$.

[18] European Network of Information Centres in the European Region - National Academic Recognition Information Centres in the European Union- ENIC/NARIC. [Online]. Available: www.enicnaric.net. [Accessed Dec. 1, 2013].

[19] Romanian National Centre for Recognition and Equivalence of Diplomas- CNRED. "Self-certification Report. Verification of compatibility of the Romanian National Qualifications Framework for Higher Education with the Framework for Qualifications of the European Higher Education Area. Document for further consultation and implementation. November 2011”. [Online]. Available:

http://cnred.edu.ro/pdf/Self_certification_Report_RO_2011.pdf. [Accessed Dec. 1, 2013].

[20] Romanian National Centre for Recognition and Equivalence of Diplomas - CNRED. [Online]. Available: http://cnred.edu.ro/en/.[Accessed Dec. 1, 2013].

[21] Romanian National Centre for Recognition and Equivalence of Diplomas - CNRED. [Online]. Available: http://www.ehea.info/Uploads/National\%20reports/Romania\%20 Rep\%20and\%20Annex.pdf.Page updated on November 2, 2012. [Accessed Dec. 1, 2013].

[22] Government Ordinance 75/2005, approved with modifications by Law 87/2006.

[23] Romanian Agency for Quality Assurance. [Online]. Available: www.aracis.ro. [Accessed Dec. 1, 2013].

[24] Government Decisions 769/2005 and 859/1995.

[25] Law of Education no. 1/2011.

[26] Government Decisions 430/2001 and 769/2005.

[27] Ministry of Education, Research, Youth and Sports. "National Report regarding the Bologna Process implementation 2009-2012". [Online]. Available: www.ehea.info/Uploads/National\%20reports/Romania\%20Rep\%2 0and\%20Annex.pdf. [Accessed Dec. 1, 2013].

[28] UE/EEA Law of Education no. 1/2011, Art. 142.

[29] Governmental Decision no. 73/2004 and Law 527/2004.

[30] Ministry of Education, Research, Youth and Sports. "National Report regarding the Bologna Process implementation 2009-2012". [Online].

Available: www.ehea.info/Uploads/National\%20reports/Romania\%20Rep\%2 0and\%20Annex.pdf. [Accessed Dec. 1, 2013].

[31] Eurostat. [Online]. Available: http://epp.eurostat.ec.europa.eu/portal/page/portal/education/data/ database. [Accessed Oct. 12, 2013].

[32] Romanian National Centre for Recognition and Equivalence of Diplomas- CNRED. "Self-certification Report. Verification of compatibility of the Romanian National Qualifications Framework for Higher Education with the Framework for Qualifications of the European Higher Education Area. Document for further consultation and implementation. November 2011". [Online]. Available:

http://cnred.edu.ro/pdf/Self_certification_Report_RO_2011.pdf. [Accessed Dec. 1, 2013].

[33] The official Bologna Process website July 2007 - June 2010. "Bologna Ministerial Anniversary Conference 2010 in Budapest and Vienna/ Questionnaire on student and staff mobility. Conducted by an Independent Assessment of the Bologna Process and presented at Bologna Ministerial Anniversary Conference in Budapest/Vienna in 2010. [Online]. Available: http://www.ond.vlaanderen.be/hogeronderwijs/bologna/2010_conf erence/.[Accessed Dec. 1, 2013].

[34] European Students' Union - ESU. "Bologna with Student Eyes 2012". Brussels, April 2012. [Online]. Available: www.aic.lv/bolona/2010_12/Reports_2012/BWSE2012-online.pdf. [Accessed Dec. 1, 2013]. 